\title{
EFFECTS OF URBAN TREE MANAGEMENT AND SPECIES SELECTION ON ATMOSPHERIC CARBON DIOXIDE
}

\author{
by David J. Nowak', Jack C. Stevens², Susan M. Sisinni ${ }^{3}$, and Christopher J. Luley ${ }^{4}$
}

\begin{abstract}
Trees sequester and store carbon in their tissue at differing rates and amounts based on such factors as tree size at maturity, life span, and growth rate. Concurrently, tree care practices release carbon back to the atmosphere based on fossil-fuel emissions from maintenance equipment (e.g., chain saws, trucks, chippers). Management choices such as tree locations for energy conservation and tree disposal methods after removal also affect the net carbon effect of the urban forest. Different species, decomposition, energy conservation, and maintenance scenarios were evaluated to determine how these factors influence the net carbon impact of urban forests and their management. If carbon (via fossil-fuel combustion) is used to maintain vegetation structure and health, urban forest ecosystems eventually will become net emitters of carbon unless secondary carbon reductions (e.g., energy conservation) or limiting decomposition via long-term carbon storage (e.g., wood products, landfills) can be accomplished to offset the maintenance carbon emissions. Management practices to maximize the net benefits of urban forests on atmospheric carbon dioxide are discussed.
\end{abstract}

Key Words. Global climate change; carbon dioxide; urban forestry; carbon sequestration.

Increasing levels of atmospheric carbon dioxide $\left(\mathrm{CO}_{2}\right)$ and other greenhouse gases [i.e., methane $\left(\mathrm{CH}_{4}\right)$, chlorofluorocarbons, nitrous oxide $\left(\mathrm{N}_{2} \mathrm{O}\right)$, and ground-level ozone $\left(\mathrm{O}_{3}\right)$ ] are thought to be contributing to an increase in atmospheric temperatures by trapping certain wavelengths of radiation in the atmosphere. However, the outcome is not straightforward because some chemicals may be reducing atmospheric temperatures (e.g., sulfur dioxide, particulate matter, upper-atmospheric ozone) (Hamburg et al. 1997; Graedel and Crutzen 1989). Globally averaged air temperature at the Earth's surface has increased between $0.3^{\circ} \mathrm{C}$ and $0.6^{\circ} \mathrm{C}\left(0.5^{\circ} \mathrm{F}\right.$ and $\left.1.1^{\circ} \mathrm{F}\right)$ since the late 1800s. A current estimate of the expected rise in average surface air temperature globally due to increasing greenhouse gas concentrations is between $1^{\circ} \mathrm{C}$ and $3.5^{\circ} \mathrm{C}$ $\left(1.8^{\circ} \mathrm{F}\right.$ and $\left.6.3^{\circ} \mathrm{F}\right)$ by the year 2100 (Hamburg et al. 1997). Global warming is suspected as a possible cause of de- clines in permanent Arctic ice of 7\% over each of the past two decades (Johannessen et al. 1999) and reductions in average ice thickness of $4.3 \mathrm{ft}(1.3 \mathrm{~m})$, or $40 \%$, between 1958 and 1997 (Rothrock et al. 1999).

Increased atmospheric $\mathrm{CO}_{2}$ is attributable mostly to fossil fuel combustion (about 80\% to 85\%) and deforestation (Hamburg et al. 1997; Schneider 1989). Atmospheric carbon is estimated to be increasing by approximately 2.6 billion metric tons (2.9 billion tons) annually (Sedjo 1989). By storing carbon through their growth process, trees act as a sink for $\mathrm{CO}_{2}$. Increasing the number of trees can potentially slow the accumulation of atmospheric carbon (e.g., Moulton and Richards 1990).

Trees sequester and store carbon in their tissue at differing rates and amounts based on such factors as size at maturity, life span, and growth rate. Concurrently, tree care practices release carbon back to the atmosphere by fossil-fuel emissions from maintenance equipment (e.g., chain saws, trucks, chippers). Thus, some of the carbon gains from tree growth are offset by carbon losses to the atmosphere via fossil fuels used in maintenance activities.

After a tree is removed, the tree eventually decomposes and the carbon stored in that tree is emitted back to the atmosphere, though a fraction of the carbon may be retained in the soil. For a given species, the maximum amount of carbon stored at one individual tree site through time is equal to the amount stored by one tree at maturity. All carbon sequestered by subsequent trees grown on that same site will be offset by carbon emissions due to decomposition of the tree previously on the site. If fossil fuels are not used in managing the vegetation, net carbon sequestered at a site cycles through time but remains positive (Figure 1).

When fossil fuels are used to manage or maintain vegetation, the carbon emissions will offset the carbon gains through time. Eventually more carbon will be emitted due to maintenance activities than will be sequestered by a tree (Figure 2). The point at which total carbon emissions become greater than total carbon se- 


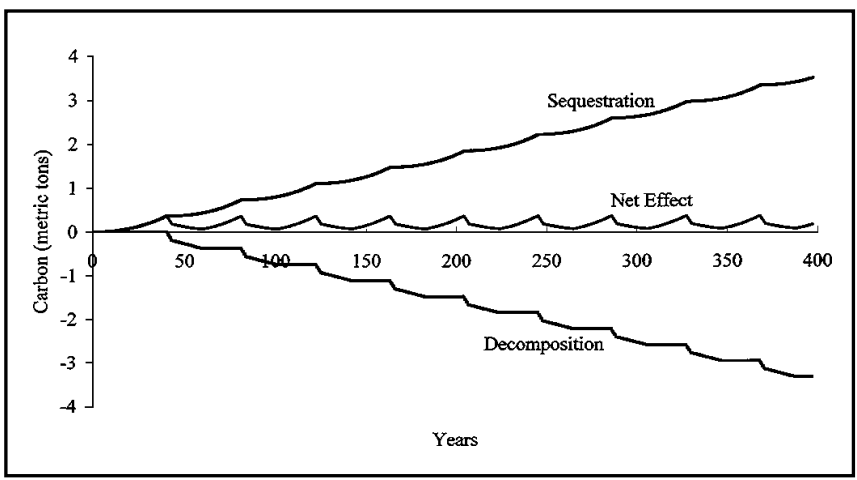

Figure 1. Cumulative annual carbon sequestration, cumulative annual carbon emission due to decomposition (mulching of tree at removal), and net annual carbon effect (sequestration - emission) for a series of red maples with a 40 -year life span.

questered (i.e., the last positive net carbon value) is referred to as the "last positive point" (LPP). This point varies depending on tree species, maintenance activities, and disposal/utilization of removed trees. The greater the LPP, the more beneficial the species and/or management activities are for reducing atmospheric carbon.

A final attribute of urban trees affecting atmospheric carbon is building energy conservation. Trees strategically located around buildings can reduce building energy use (e.g., Heisler 1986) and consequently lower carbon emissions from fossil-fuel-burning power plants. The energy savings from trees can increase the LPP and help offset carbon emissions from maintenance. The energy-conserving potential of urban trees

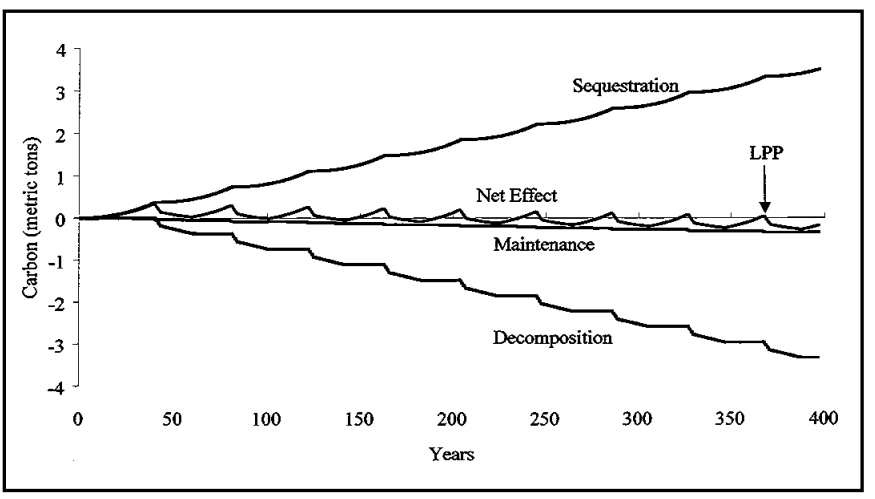

Figure 2. Cumulative annual carbon sequestration, cumulative annual carbon emission due to decomposition (mulching of tree at removal), cumulative annual carbon emissions due to tree maintenance (conservative maintenance scenario), and net annual carbon effect (sequestration - decomposition emission - maintenance emission) for a series of red maples with a 40 -year life span. LPP $=$ Last positive point. is considered as a final component of the urban tree carbon cycle analysis.

The objectives of this study are 1) to determine how tree species under the same management and decomposition regime differ in net carbon benefits; 2) to illustrate for one species how maintenance activities, method of disposal/use of removed trees, and energy conservation by trees can affect the timing and overall carbon benefits derived from urban trees; and 3) to present management strategies that optimize the net impact of urban forestry on reducing atmospheric carbon dioxide.

\section{METHODS}

\section{Maintenance Emissions}

Three maintenance scenarios were modeled. "Low carbon maintenance" utilized a light-duty truck to transport the tree, crew, and materials; trees were hand-planted, and there were no return trips to the tree after planting. "Conservative carbon maintenance" used one light-duty and one heavy-duty truck to transport crew and materials to the planting site where the tree was planted using a backhoe. There was a return visit the year following planting in a light-duty truck to remove guy-wires, to hand prune, etc. Pruning was conducted every 15 years and involved a light-duty truck, an aerial-lift truck towing a chipper, and different chain saws depending upon tree size (Table 1). "Intensive carbon maintenance" was similar to conservative maintenance except the tree was pruned every 7 years and the crew returned once later in the planting year to water and care for the tree.

For all maintenance regimes, the tree was removed using a light-duty truck, an aerial-lift truck towing a chipper, a heavy-duty truck hauling a stump grinder, and different chain saws depending on tree size (Table 1). Sixteen $\mathrm{km}(10 \mathrm{mi})$ of round-trip mileage was input for all maintenance scenarios. Calculations of carbon emissions for vehicles were based on $7.5 \mathrm{~km} / \mathrm{L}(17.7 \mathrm{mpg})$ for lightduty trucks (Murrell et al. 1993), $2.6 \mathrm{~km} / \mathrm{L}(6.1 \mathrm{mpg})$ for heavy-duty trucks (Davis 1994), and $0.7 \mathrm{~kg}$ of carbon per liter of fuel (6 lb carbon per gallon) (Graham et al. 1992). These fuel carbon values include the carbon in the fuel as well as the carbon emissions associated with refining and transporting the fuel.

Calculations for emissions from chain saws, chippers, aerial lifts, backhoes, and stump grinders are based on the formula:

$$
\mathrm{C}=\mathrm{N} \times \mathrm{HRS} \times \mathrm{HP} \times \mathrm{LF} \times \mathrm{E}
$$

where $\mathrm{C}=$ carbon emissions $(\mathrm{g}), \mathrm{N}=$ number of units, HRS $=$ hours used, HP $=$ average rated horsepower, 
$\mathrm{LF}=$ typical load factor, and $\mathrm{E}=$ average carbon emissions per unit of use (g/hp/hr) (U.S. EPA 1991). Hours used and typical horsepower for maintenance equipment are given in Table 1; typical load factors and average carbon emissions for equipment are given in Table 2 .

\section{Decomposition Emissions}

Two common tree disposal/utilization scenarios were modeled: 1) mulching and 2) landfill. Although no mulch decomposition studies could be found, studies on decomposition of tree roots and twigs reveal that $50 \%$ of the carbon is lost within the first 3 years (Scheu and Schauermann 1994). The remaining carbon is estimated to be lost within 20 years of mulching. Belowground biomass of trees averages approximately $22 \%$ of total tree biomass (e.g., Hermann 1977). Belowground biomass was modeled to decompose at the same rate as mulch regardless of how the aboveground biomass was disposed.

For aboveground biomass that is disposed in a landfill, only $3.7 \%$ of the carbon is released during the first 5 years (Micales and Skog 1997). The remaining carbon is permanently locked up in functional landfills.

\section{Species Comparisons}

One hundred common urban tree species were categorized by life span, growth rate, and size at maturity (Table 3). From this list, one species was selected within each major tree growth category (14 categories) based on availability of tree biomass equations with wide diameter ranges (Table 4). Total tree dry-weight biomass was calculated using these formulas based on tree diameter at $1.37 \mathrm{~m}(4.5 \mathrm{ft})(\mathrm{dbh})$ and methods of converting aboveground to total biomass and/or fresh-weight to

Table 1. Total hours of equipment run-time by dbh class for tree pruning and removal. Table is based on ACRT data (Wade and Dubish, pers. comm. 1995) and assumes crews work efficiently and equipment is not run idle.

\begin{tabular}{|c|c|c|c|c|c|c|c|c|c|c|}
\hline \multirow[b]{2}{*}{ Dbh } & \multicolumn{4}{|c|}{ Pruning } & \multicolumn{6}{|c|}{ Removal } \\
\hline & $\begin{array}{l}2.3-h p \\
\text { saw }\end{array}$ & $\begin{array}{l}\text { 3.7-hp } \\
\text { saw }\end{array}$ & $\begin{array}{l}\text { Bucket } \\
\text { truck }^{z}\end{array}$ & Chipper $^{\mathrm{y}}$ & $\begin{array}{l}\text { 2.3-hp } \\
\text { saw }\end{array}$ & $\begin{array}{l}\text { 3.7-hp } \\
\text { saw }\end{array}$ & $\begin{array}{l}\text { 7.5-hp } \\
\text { saw }\end{array}$ & $\begin{array}{l}\text { Bucket } \\
\text { truck }^{z}\end{array}$ & Chipper $^{y}$ & $\begin{array}{l}\text { Stump } \\
\text { grinder }\end{array}$ \\
\hline $1-6$ & 0.05 & NA & NA & 0.05 & 0.3 & NA & NA & 0.2 & 0.1 & 0.25 \\
\hline $7-12$ & 0.1 & NA & 0.2 & 0.1 & 0.3 & 0.2 & NA & 0.4 & 0.25 & 0.33 \\
\hline $13-18$ & 0.2 & NA & 0.5 & 0.2 & 0.5 & 0.5 & 0.1 & 0.75 & 0.4 & 0.5 \\
\hline $19-24$ & 0.5 & NA & 1.0 & 0.3 & 1.5 & 1.0 & 0.5 & 2.2 & 0.75 & 0.7 \\
\hline $25-30$ & 1.0 & NA & 2.0 & 0.35 & 1.8 & 1.5 & 0.8 & 3.0 & 1.0 & 1.0 \\
\hline $31-36$ & 1.5 & 0.2 & 3.0 & 0.4 & 2.2 & 1.8 & 1.0 & 5.5 & 2.0 & 1.5 \\
\hline $36+$ & 1.5 & 0.2 & 4.0 & 0.4 & 2.2 & 2.3 & 1.5 & 7.5 & 2.5 & 2.0 \\
\hline
\end{tabular}

${ }^{2}$ Mean HP $=43$ (U.S. EPA 1991)

${ }^{{ }^{\prime}}$ Mean HP $=99$ (U.S. EPA 1991)

Table 2. Typical load factors (U.S. EPA 1991), average carbon emissions, and total carbon emissions for various maintenance equipment.

\begin{tabular}{llll}
\hline Equipment & Typical load factor & Average C emission $(\mathrm{g} / \mathrm{hp} / \mathrm{hr})^{\mathrm{y}}$ & Total C emission $(\mathrm{kg} / \mathrm{hr})^{\mathrm{x}}$ \\
\hline Aerial lift & 0.505 & 147.2 & $3.2^{\mathrm{w}}$ \\
Backhoe & 0.465 & 147.3 & $5.3^{\mathrm{v}}$ \\
Chain saw $<4 \mathrm{hp}$ & 0.500 & $1,264.4$ & $1.5^{\mathrm{u}}$ \\
Chain saw $>4 \mathrm{hp}$ & 0.500 & 847.5 & $3.2^{\mathrm{t}}$ \\
Chipper/stump grinder & 0.370 & 146.4 & $5.4^{\mathrm{s}}$ \\
\hline
\end{tabular}

${ }^{2}$ Average value from two inventories (conservative load factor of 0.5 from one inventory was used for chain saws $>4$ hp due to disparate inventory estimates; inventory average for this chain saw type was 0.71 )

${ }^{y}$ Calculated from estimates of carbon monoxide (U.S. EPA 1991), hydrocarbon crankcase and exhaust (U.S. EPA 1991), and carbon dioxide emissions

(Charmley, pers. comm. 1995) adjusted for in-use effects. Total carbon emissions were calculated based on the proportion of carbon of the total atomic weight of the chemical emission. Multiply by 0.0022 to convert to $\mathrm{lb} / \mathrm{hp} / \mathrm{hr}$.

${ }^{\mathrm{x}}$ Multiply by 2.2 to convert to $\mathrm{lb} / \mathrm{hr}$.

wMean HP $=43$ (U.S. EPA 1991).

${ }^{\mathrm{v}}$ Mean HP $=77$ (U.S. EPA 1991).

"HP $=2.3$.

${ }^{\mathrm{t}} \mathrm{HP}=7.5$.

${ }^{\mathrm{s}}$ Mean HP $=99$ (U.S. EPA 1991). 
dry-weight biomass (Nowak 1994). Total tree biomass predicted by forest-derived biomass equations tends to overestimate by $25 \%$ the biomass of urban trees that are intensively pruned (Nowak 1994). As most urban trees do not receive this high degree of pruning, forest-derived biomass estimates were multiplied by 0.9 to compensate for likely differences in biomass equation estimates between forest and urban trees. Dry-weight biomass was converted to carbon by dividing by two (Ajtay et al. 1979).

Each tree was modeled to grow to expected life span, be removed and replanted with the same species continually through time until the LPP was reached. All trees had the same maintenance (conservative) and decomposition (mulching) scenarios. Total carbon stored at each year was calculated for each species based on estimated annual growth (i.e., projected $\mathrm{dbh}$ ) in conjunction with species-specific biomass formulas. At time of planting (year 1), each tree was modeled as $2.5 \mathrm{~cm}$ (1 in.) dbh and $2.4 \mathrm{~m}(8 \mathrm{ft})$ in height based on nursery plant standards (American Association Nurserymen 1986). Slow-, moderate-, and fast-growing species were given diameter growth rates of $0.58,0.84$, and $1.09 \mathrm{~cm} / \mathrm{yr}(0.23,0.33$, and $0.43 \mathrm{in} . / \mathrm{yr})$, respectively, based on growth data from Fleming (1988) and Nowak (1994). Short-lived species were modeled to live 20 years; moderatelived species 40 years; and long-lived species 60 years.
Cumulative net carbon was calculated as

$$
\mathrm{N}_{\mathrm{c}}=\mathrm{S}_{\mathrm{c}}-\mathrm{E}_{\mathrm{m}}-\mathrm{E}_{\mathrm{d}}
$$

where $N_{c}$ is net cumulative carbon, $S_{c}$ is cumulative carbon stored in trees, $\mathrm{E}_{\mathrm{m}}$ is cumulative carbon emitted by fossil-fuel use for maintaining the trees (carbon emissions used to produce planting stock were not included in this analysis), and $E_{d}$ is cumulative carbon emitted through decomposition of removed trees (decomposition did not start until the first tree was removed). Annual cumulative carbon calculations were computed until net cumulative carbon crossed from positive values to negative values for the last time (i.e., LPP; no positive carbon values after this year).

\section{Maintenance-Decomposition Comparisons}

To compare the effects of varying maintenance and decomposition scenarios on the LPP, species effects were held constant by using only one species: red maple (Acer rubrum). To compare maintenance effects, red maple was modeled using the low, conservative, and intensive carbon maintenance scenarios with mulch decomposition to illustrate how LPPs vary with maintenance fossil-fuel inputs. A similar maintenance comparison was also made, but with the assumption that increased maintenance (fossil-fuel

Table 3. One hundred common urban tree species categorized by size at maturity, life span, and height growth rate [based on data from Dirr (1990), Hightshoe (1978), Collingwood and Brush (1964), Clark (1985), and Burns and Honkala (1990a, 1990b)]*.

Large-sized, long-lived, moderate to fast growth rate: Aesculus hippocastanum, Juglans nigra, Liquidambar styraciflua, Pinus ponderosa, P. resinosa, P. strobus, Platanus acerifolia, P. occidentalis, Pseudotsuga menziessi, Quercus coccinea, Q. rubra, Q. virginia, Taxodium distichum.

Large-sized, long-lived, slow growth rate: Betula alleghaniensis, Carya illinoensis, C. laciniosa, Fagus grandifolia, Ginkgo biloba, Picea rubens, Quercus alba, Q. kelloggii, Q. macrocarpa, Q. prinus (montana).

Large-sized, medium-lived, moderate to fast growth rate: Celtis laevigata, Fraxinus americana, Gymnocladus dioicus, Larix laricina, Liriodendron tulipifera, Magnolia acuminata, Pinus elliottii, P. palustris, Quercus palustris, Tilia americana, T. cordata, Ulmus americana, U. pumila.

Large-sized, medium-lived, slow growth rate: Abies balsamea, Acer macrophyllum, A. saccharum, Carya cordiformis, C. ovata, Ulmus thomasii.

Large-sized, short-lived, moderate to fast growth rate: Acer saccharinum, Betula papyrifera, Magnolia grandifolia, Populus deltoides, P. grandidentata, Quercus nigra.

Medium-sized, long-lived, moderate growth rate: Picea abies, P. glauca, Quercus phellos, Thuja occidentalis, Tsuga canadensis.

Medium-sized, long-lived, slow growth rate: Carya glabra, C. tomentosa, Juniperus virginiana, Picea pungens, Quercus donglasii, Q. lobata, Q. muehlenbergii.

Medium-sized, medium-lived, fast growth rate: Celtis occidentalis, Fraxinus pennsylvanica, Gleditsia triacanthos, Pinus echinata, P. taeda, Prunus serotina, Ulmus serotina.

Medium-sized, medium-lived, moderate growth rate: Acer rubrum, Pinus nigra, P. sylvestris, Quercus bicolor, Q. velutina, Ulmus parvifolia, U. rubra.

Medium-sized, short-lived, fast growth rate: Acer negundo, Ailanthus altissima, Alnus glutinosa, Catalpa speciosa, Morus rubra, Pinus banksiana, Populus tremuloides, Quercus laurifolia, Robinia pseudoacacia, Salix nigra.

Medium-sized, short-lived, moderate growth rate: Acer platanoides, Betula nigra, Sassafras albidum.

Small-sized, long-lived, slow growth rate: Quercus chrysolepsis, Q. lyrata.

Small-sized, medium-lived, slow to moderate growth rate: Aesculus glabra, Cornus florida, Ilex opaca, Ostrya virginiana, Picea mariana. Small-sized, short-lived, any growth rate: Cercis canadensis, Crataegus spp., Malus spp., Pinus virginiana, Prunus pennsylvanica, Sorbus americana.

*Species may change categories based on local conditions. 
Table 4. Summary of tree size, life span, height growth rates, and biomass equations for 14 species analyzed. Last positive points (LPP) are based on conservative maintenance and mulch decomposition scenarios. Greater LPPs are most desirable in terms of carbon benefits.

\begin{tabular}{|c|c|c|c|c|c|c|}
\hline \multirow[b]{2}{*}{ Species } & \multicolumn{2}{|c|}{ LPP } & \multirow[b]{2}{*}{ Size $(h t)^{y}$} & \multirow[b]{2}{*}{ Life $\operatorname{span}^{x}$} & \multirow[b]{2}{*}{ Growth rate ${ }^{\mathrm{w}}$} & \multirow[b]{2}{*}{ Biomass equation } \\
\hline & Yrs & $\mathrm{Gen}^{2}$ & & & & \\
\hline Liquidambar styraciflua & 960 & 16 & $\mathrm{~L}$ & $\mathrm{~L}$ & M & Schlaegel $1984 c$ \\
\hline Liriodendron tulipifera & 720 & 18 & $\mathrm{~L}$ & $\mathrm{M}$ & $\mathrm{F}$ & Tritton and Hornbeck 1982 \\
\hline Quercus alba & 720 & 12 & $\mathrm{~L}$ & $\mathrm{~L}$ & S & Tritton and Hornbeck 1982 \\
\hline Fraxinus pennsylvanica & 480 & 12 & M & M & $\mathrm{F}$ & Schlaegel 1984a \\
\hline Quercus lyrata & 480 & 8 & $\mathrm{~S}$ & $\mathrm{~L}$ & S & Schlaegel 1984b \\
\hline Quercus phellos & 420 & 7 & M & $\mathrm{L}$ & M & Schlaegel 1981 \\
\hline Picea pungens & 420 & 7 & M & $\mathrm{L}$ & S & Tritton and Hornbeck 1982 \\
\hline Acer rubrum & 360 & 9 & M & M & M & Tritton and Hornbeck 1982 \\
\hline Acer saccharum & 240 & 6 & $\mathrm{~L}$ & M & S & Tritton and Hornbeck 1982 \\
\hline Picea mariana & 160 & 4 & $\mathrm{~S}$ & $\mathrm{M}$ & S & Tritton and Hornbeck 1982 \\
\hline Populus deltoides & 60 & 3 & $\mathrm{~L}$ & $\mathrm{~S}$ & $\mathrm{~F}$ & Wenger 1984 \\
\hline Pinus banksiana & 60 & 3 & $\mathrm{M}$ & $\mathrm{S}$ & $\mathrm{F}$ & Stanek and State 1978 \\
\hline Betula nigra & 60 & 3 & M & $\mathrm{S}$ & M & Tritton and Hornbeck 1982 \\
\hline Prunus pennsylvanica & 60 & 3 & $\mathrm{~S}$ & $\mathrm{~S}$ & $\mathrm{~F}$ & Tritton and Hornbeck 1982 \\
\hline
\end{tabular}

${ }^{2}$ Number of generations.

${ }^{\mathrm{y}} \mathrm{L}=$ large $>60 \mathrm{ft} ; \mathrm{M}=$ medium $40-60 \mathrm{ft} ; \mathrm{S}=$ small $<40 \mathrm{ft}$. Based on data primarily from Dirr (1990). Secondary data sources include

Collingwood and Brush (1964), Clark (1985), and Burns and Honkala (1990a, 1990b).

${ }^{\mathrm{x}} \mathrm{L}=$ long >200 yr; $\mathrm{M}=$ medium 100-200 yr; $\mathrm{S}=$ short <100 yr. Based on data primarily from Hightshoe (1978). Secondary data sources include Collingwood and Brush (1964), Clark (1985), and Burns and Honkala (1990a, 1990b).

${ }^{\mathrm{w}} \mathrm{F}=$ fast $>24 \mathrm{in./yr} ; \mathrm{M}=$ moderate $12-24 \mathrm{in./yr} ; \mathrm{S}=$ slow $<12 \mathrm{in.} / \mathrm{yr}$. Based on data primarily from Hightshoe (1978). Secondary data sources include Collingwood and Brush (1964), Clark (1985), and Burns and Honkala (1990a, 1990b).

emissions) increased tree life span. Under low maintenance, red maple life span was 20 years, under conservative maintenance 40 years, and under intensive maintenance 60 years. Effects of different tree decomposition (mulch, landfill, burn) on the LPP were also illustrated using red maple under a conservative maintenance scenario.

\section{Energy Conservation}

To determine the effect of trees in energy-conserving locations, red maple was modeled with conservative maintenance and mulch decomposition but was located at an optimal energy-conserving site near a building. Energy effects of one 7.6-m (25-ft) tree (shade effects on one-story, $139-\mathrm{m}^{2}\left[1,500 \mathrm{ft}^{2}\right]$ residence) were listed for 13 cities across the United States (McPherson et al. 1993; McPherson 1994). Median energy effect values were used in this study for building cooling (average annual savings of $218 \mathrm{kWh}$ ) and heating (average annual increase of $0.5 \mathrm{MBtu}$ ).

Building cooling energy savings were converted to savings in carbon emissions based on the U.S. national average of $588 \mathrm{~kg} \mathrm{CO} / \mathrm{MWh}$ or $0.16 \mathrm{~kg} \mathrm{C} / \mathrm{kWh}(1,296 \mathrm{lb} \mathrm{CO} /$ MWh; $0.353 \mathrm{lb} \mathrm{C} / \mathrm{kWh}$ ) (U.S. Dept. of Energy 1994). Building heating increases were converted to increased carbon emissions based on natural gas emissions of 52.8 mil- lion metric tons $\mathrm{CO}_{2} /$ quadrillion Btu or $14.4 \mathrm{~kg} \mathrm{C} / \mathrm{MBtu}$ (58.2 million tons $\mathrm{CO}_{2}$ /quadrillion Btu; $31.7 \mathrm{lb} \mathrm{C/MBtu}$ ) (U.S. Dept. of Energy 1994). The net carbon emission avoidance for a $7.6-\mathrm{m}(25-\mathrm{ft})$ deciduous tree was $27.7 \mathrm{~kg} \mathrm{C}$ per year $(61.1 \mathrm{lb} \mathrm{C/yr})$.

A tree between 4.6 and $7.6 \mathrm{~m}$ (15 and $25 \mathrm{ft})$ was given an energy effect proportional to its tree height, with trees less than $4.6 \mathrm{~m}$ given no energy effects and trees $7.6 \mathrm{~m}$ or taller equaling $27.7 \mathrm{~kg} \mathrm{C} / \mathrm{yr}(61.1 \mathrm{lb} \mathrm{C} / \mathrm{yr})$. Tree height growth rates were estimated based on mature tree height divided by maximum expected life span for each species. Rates ranged from $0.1 \mathrm{~m} / \mathrm{yr}(0.32 \mathrm{ft} / \mathrm{yr})$ (Quercus lyrata) to $0.61 \mathrm{~m} / \mathrm{yr}(2.0 \mathrm{ft} / \mathrm{yr}$ ) (Populus deltoides). Modeled height growth was comparable to height growth exhibited for street trees in New Jersey (Fleming 1988).

Cumulative net carbon for energy conserving trees was calculated as

$$
\mathrm{N}_{\mathrm{c}}=\mathrm{S}_{\mathrm{c}}+\mathrm{A}_{\mathrm{c}}-\mathrm{E}_{\mathrm{m}}-\mathrm{E}_{\mathrm{d}}
$$

where $N_{c}$ is net cumulative carbon, $S_{c}$ is cumulative carbon stored in trees, $\mathrm{A}_{c}$ is avoided carbon emission due to energy conservation, $\mathrm{E}_{\mathrm{m}}$ is cumulative carbon emitted by fossil-fuel use for maintaining the trees, and $E_{d}$ is cumulative carbon emitted through decomposition of removed trees. 


\section{RESULTS AND DISCUSSION}

Any forest system that is continually maintained with fossil-fuel use eventually will emit more carbon than can be removed by the vegetation in the system, unless the forest is used to offset all maintenance carbon emissions (e.g., through building energy conservation). Thus, the objective in maintaining a fossil-fuel-managed forest system is to forestall the eventual carbon LPP (where carbon emission is greater than carbon sequestration) to the farthest point in the future, or preferably, that the LPP is never reached. Critical forest management factors in maximizing carbon benefits include species composition, life span, maintenance, decomposition, and energy conservation.

\section{Species Composition Effects}

Tree species classes showed a wide range of effects on the carbon LPP with large (at maturity), long-lived, moderate-growth species having the longest LPP at 960 years and short-lived trees having the shortest LPP at 60 years (Table 4). Tree life span appears to have the greatest effect on the LPP with long-lived species generally having higher LPPs than moderate-lived species, which had higher LPPs than short-lived species. Life span is important in the urban forest carbon cycle because the longer the tree lives, the longer the carbon emissions due to tree planting and removals are forestalled into the future.

As life span varied for a red maple with conservative maintenance and mulch decomposition scenarios, LPPs varied from zero years [an annual emission of $9.5 \mathrm{~kg} \mathrm{C} /$ yr $(21 \mathrm{lb} \mathrm{C} / \mathrm{yr})]$ for a 1-year life span, to 2,400 years for a red maple with a 100-year life span (Table 5). Trees planted in urban areas need to live a minimum amount of time (between 5 and 10 years for this red maple scenario) to compensate for the base carbon emissions used in planting, establishment, and tree removal. If trees do not live the minimum numbers of years to compensate for the base carbon emissions, sustaining that tree population will lead to net emissions of carbon throughout the life cycle of the tree population (i.e., there never will be any net carbon sequestration benefits).

The longer a tree's life span-assuming no increase in maintenance to achieve the longer life-the greater the carbon benefit received from the tree. Planting trees in locations that allow the tree to reach a large size at maturity, promote tree health, increase life spans, and minimize maintenance will provide significant carbon benefits and increase the number of years before the carbon LPP is reached.
Table 5. The effect of tree life span on the last positive point. Estimates are for red maple with conservative maintenance and mulching decomposition scenario.

\begin{tabular}{ll}
\hline Life span (yrs) & Last positive point \\
\hline 1 & None [emission of $9.5 \mathrm{~kg} \mathrm{C} / \mathrm{yr}(21 \mathrm{lb} \mathrm{C} / \mathrm{yr})]$ \\
5 & None [average emission of $2.3 \mathrm{~kg} \mathrm{C} / \mathrm{yr}(5 \mathrm{lb} \mathrm{C} / \mathrm{yr})]$ \\
10 & 10 years $(1$ generation) \\
25 & 125 years (5 generations) \\
50 & 650 years (13 generations) \\
100 & 2,400 years (24 generations) \\
\hline
\end{tabular}

Other important tree factors affecting the LPP are size of tree and growth rate. Given the same life span and growth rate, larger trees at maturity will sequester more carbon than smaller trees and have higher LPPs. Growth rates will affect net sequestration if the tree does not live long enough to reach mature size. In this case, faster growth acts as a type of carbon insurance policy because a faster-growing tree will sequester its carbon sooner. For example, two different species store 3 tons of carbon at maturity and live 100 years, but one species reaches mature size after 10 years (fast growth) and the other after 90 years (slow growth). If these trees live only 50 years, the fast-growing tree will have sequestered more carbon. However, if both species live to maturity (100 years), there is no difference in carbon storage. Overall, the two most important species factors in increasing net sequestration appear to be life span and tree size at maturity.

\section{Maintenance Effects}

Tree maintenance has a negative effect on the carbon budget unless tree maintenance leads to an increased life span. If a red maple lives 40 years regardless of maintenance, the LPP would be 680 years with minimal maintenance, but only 240 years with intensive maintenance (Table 6). However, if maintenance directly affects life span, increased maintenance can increase the LPP (Table 6).

Field studies indicate that mortality rates of newly established trees are often higher than for established trees (e.g., Nowak et al. 1990). Maintenance efforts (e.g., watering) during the early establishment phase of tree growth can potentially lead to carbon benefits by increasing tree life spans. Pruning of established trees, though important for safety and other reasons, is likely to have a lesser carbon benefit, though young tree pruning can reduce the need for pruning as the tree ages. It currently is difficult to determine the amount, if any, that tree pruning increases the life span of a tree. The greater the effect of pruning on increasing tree life spans, the greater the car- 
bon benefit. More research is needed on quantifying how tree pruning ultimately affects tree longevity.

Generally, if carbon-based maintenance is performed on trees, though important for many reasons, there will be a net carbon loss if life span is not increased. One option to avoid these carbon costs is to use non-fossil-fuel-based tree maintenance (e.g., using rakes instead of leaf blowers or hand saws instead of chain saws where feasible).

\section{Decomposition Effects}

How wood from removed trees is used or discarded has a direct impact on the LPP. If wood is sealed within a functional landfill, carbon decomposition is minimal and a LPP is not reached (i.e., net carbon sequestration is greater than decomposition) (Figure 3). However, landfills have limited space and green waste is often prohibited.

Other options that provide benefits by helping lengthen the LPP are 1) using wood in long-term products (e.g., lumber, furniture) where decomposition is delayed into the future, although carbon-based products (e.g., stains, paints) may be used to limit decomposition; or 2) using wood for energy production to reduce fossilfuel combustion (e.g., burn wood for heat to reduce use of fossil-fuel-based heating systems). Rapid carbon release from wood (e.g., burning within a few years of tree removal) without reduction in fossil-fuel-based heating use will have negative impacts by significantly shortening the LPP.

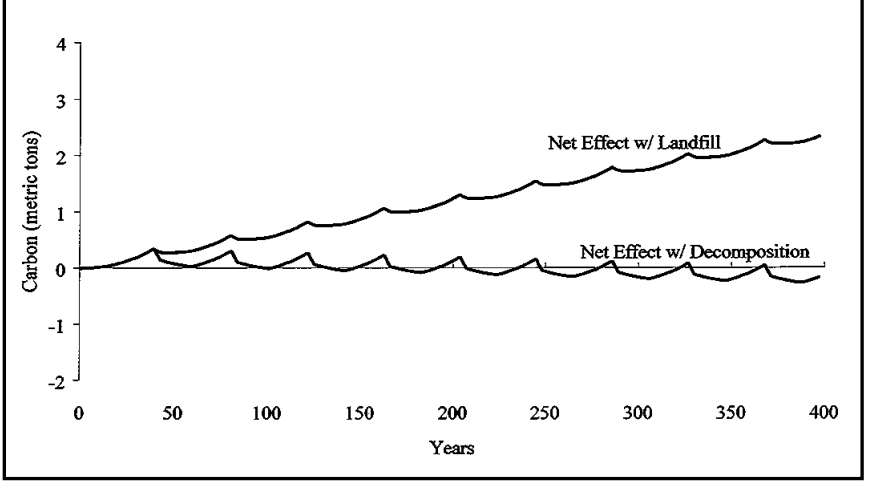

Figure 3. Comparison of net carbon effect of a red maple with a 40-year life span when removed tree decomposes via mulching (decomposition) vs. removed tree being buried in a landfill.

\section{Energy Conservation Effects}

Planting trees in energy-conserving locations around buildings (e.g., Heisler 1986) reduces carbon emissions from fossil-fuel-based power plants that more than compensates for maintenance carbon emissions (Figure 4). Trees in energy-conserving locations lead to an annual net benefit of carbon reduction with a cumulative impact that increases through time. These secondary effects are likely more important than the primary effects of direct carbon sequestration because most carbon stored by trees eventually will be released to the atmosphere through decomposition after the tree dies, though a fraction of the carbon can be retained in the soil. Secondary tree effects that avoid carbon emissions are of permanent benefit to reducing global climate change. Therefore, energy-conserving sites are the best location for trees in urban areas to conserve carbon due to their relatively significant effect on reducing carbon emissions associated with building climate control and the permanent nature of the carbon reduction. In addition, trees in non-energy-conserving sites also can have an overall impact on reducing urban carbon emissions by reducing air temperatures and consequent emissions associated with urban heat islands.

Urban forests in the United States currently store about 700 million metric tons ( 775 million tons) of carbon (Nowak and Crane 2001), but the amount of carbon used to sustain this vegetation remains unknown. Although carbon storage in urban trees nationally is only a fraction $(4.4 \%)$ of the carbon stored by trees in U.S. nonurban forest ecosystems (Birdsey and Heath 1995), the relatively high secondary effects of reducing carbon emissions gives urban trees a greater per-tree effect on reducing greenhouse gas concentrations than nonurban trees.

When forest land is cleared to make space for urban development, the new urban areas are in an immediate 


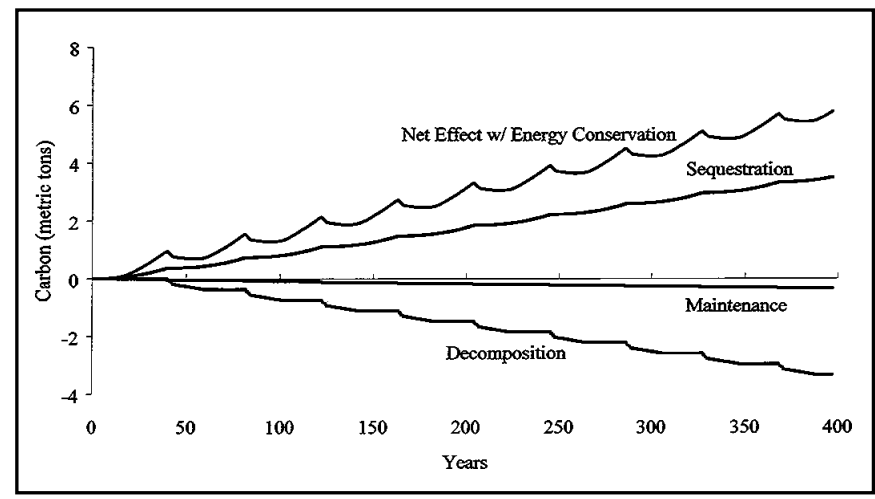

Figure 4. Cumulative annual carbon sequestration, cumulative annual carbon emission due to decomposition (mulching of tree at removal), cumulative annual carbon emissions due to tree maintenance (conservative maintenance scenario), and net annual carbon effect when tree is planted next to a building to conserve energy (sequestration decomposition emission - maintenance emission + reduction in carbon emissions from power plants due to energy conservation) for a series of red maples with a 40 -year life span.

carbon deficit due to loss of carbon from the deforestation process. Urban forest cover that is added to these developments will only partially regain the carbon lost from forest clearing. In grasslands and other nonforest areas, urbanization tends to increase tree cover and carbon storage but also significantly increases carbon emissions associated with sustaining urban ecosystems.

Loss of current urban forest cover will lead to an increase in global atmospheric carbon, whereas increased urban tree cover that is sustained will have a net impact of reducing atmospheric carbon levels until the LPP for the population is reached. Thus, vegetation managed via fossil-fuel use is only a temporary means to reduce atmospheric carbon. Reducing carbon emissions (e.g., via building energy conservation from trees) provides a permanent reduction in global atmospheric carbon. Carbon accounting within urban forest ecosystems should account for both carbon sequestration and emissions (including avoided emissions) to determine the net carbon benefits for society. The numbers given in this paper illustrate the effects of urban trees and their maintenance on atmospheric carbon dioxide. The numbers presented are dependent on the scenario used, but they reveal the general impact of tree life span, growth rates, tree size, and maintenance choices on the global carbon cycle.

\section{CONCLUSIONS}

Carbon released through tree management activities needs to be accounted for to calculate the net effect of urban forestry on atmospheric carbon dioxide. If carbon (in fossil fuels) is used to maintain vegetation structure and health, the forest ecosystem eventually will become a net emitter of carbon unless secondary carbon reductions (e.g., energy conservation) or limiting of decomposition via long-term carbon storage (e.g., wood products, landfills) can be accomplished to offset the maintenance carbon emissions. Management choices related to species composition and types of tree maintenance activities directly affect the overall carbon benefits derived from urban forests. To maximize the net benefits of urban forestry on atmospheric carbon dioxide, urban forest managers should focus on

- planting long-lived, low-maintenance, moderateto fast-growing species that are large at maturity and matched to site conditions;

- using maintenance activities that increase tree survival and longevity;

- minimizing fossil-fuel use related to management and maintenance activities;

- using wood from removed trees to delay decomposition or decrease the need for energy from fossil-fuel-based power plants (e.g., develop longterm wood products; burn wood to heat residences); and

- planting trees in energy-conserving locations.

\section{LITERATURE CITED}

Ajtay, G.L., P. Ketner, and P. Duvingneaud. 1979. Terrestrial primary production and phytomass, pp 129-181. In Bolin, B., E.T. Degens, S. Kempe, and P. Ketner, P. (Eds.). The Global Carbon Cycle. SCOPE Rep. 13. John Wiley and Sons, New York, NY.

American Association of Nurserymen. 1986. American Standard for Nursery Stock. American Association of Nurserymen, Inc., Washington, DC. 32 pp.

Birdsey, R.A., and L.S. Heath. 1995. Carbon changes in U.S. forests, pp 56-70. In Joyce, L.A. (Ed.). Climate Change and the Productivity of America's Forests. Gen. Tech. Rep. RM271, USDA Forest Service, Rocky Mountain Research Station, Fort Collins, CO.

Burns, R.M., and B.H. Honkala (Tech. Coords.). 1990a. Silvics of North America Volume 1, Conifers. Agriculture Handbook 654. USDA Forest Service, Washington, DC. 675 pp.

Burns R.M., and B.H. Honkala (Tech. Coords.). 1990b. Silvics of North America Volume 2, Hardwoods. Agriculture Handbook 654. USDA Forest Service, Washington, DC. 877 pp. 
Clark, D.E. (Ed.) 1985. Sunset New Western Garden Book. Lane Publishing Co., Menlo Park, CA. 512 pp.

Collingwood, G.H., and W.D. Brush. 1964. Knowing Your Trees. The American Forestry Association, Washington, DC. 349 pp.

Davis, S.C. 1994. Transportation Energy Data Book (14th Ed.). Publ. ORNL-6798. Oak Ridge National Laboratory, Oak Ridge, TN.

Dirr, M.A. 1990. Manual of Woody Landscape Plants: Their Identification, Ornamental Characteristics, Culture, Propagation and Uses. Stipes Publishing Company, Champaign, IL. 1007 pp.

Fleming, L.E. 1988. Growth Estimates of Street Trees in Central New Jersey. M.S. thesis. Rutgers University, New Brunswick, NJ. 143 pp.

Graedel, T.E., and P.J. Crutzen. 1989. The changing atmosphere. Sci.Am. 261(3):58-68.

Graham, R.L., L.L. Wright, and A.F. Turhollow. 1992. The potential for short-rotation woody crops to reduce U.S. $\mathrm{CO}_{2}$ emissions. Clim. Change 22:223-238.

Hamburg, S.P., N. Harris, J. Jaeger, T.R. Karl, M. McFarland, J.F.B. Mitchell, M. Oppenheimer, S. Santer, S. Schneider, K.E. Trenberth, and T.M.L.Wigley. c. 1997. Common Questions About Climate Change. United Nation Environment Programme, World Meteorological Organization, Geneva, Switzerland. 24 pp.

Heisler, G.M. 1986. Energy savings with trees. J. Arboric. 12(5):113-125.

Hermann, R.K. 1977. Growth and production of tree roots: A review, pp 7-27. In Marshall, J.K. (Ed.). The Belowground Ecosystem: A Synthesis of Plant-Associated Processes. Sci. Ser. No. 26. Range Science Department, Colorado State University, Fort Collins, CO.

Hightshoe, G.L. 1978. Native Trees, Shrubs, and Vines for Urban and Rural America. Van Nostrand Reinhold, New York, NY. 819 pp.

Johannessen, O.M., E.V. Shalina, and M.W.Wiles. 1999. Satellite evidence for an Arctic sea ice cover in transformation. Science 286:1937-1939.

McPherson, E.G., P. Sacamano, and S. Wensman. 1993. Modeling Benefits and Costs of Community Tree Plantings: A Demonstration Project. Final Report to American Forests, US EPA, US DOE, USDA Forest Service. USDA Forest Service, Northeastern Forest Experiment Station, Chicago, IL. 169 pp.

McPherson, E.G. 1994. Energy-saving potential of trees in Chicago, pp 95-113. In McPherson, E. G., D.J. Nowak, and R.A. Rowntree (Eds.). Chicago's Urban Forest Ecosystem: Results of the Chicago Urban Forest Climate Project. Gen. Tech. Rep. NE-186. USDA Forest Service, Northeastern Forest Experiment Station, Radnor, PA.

Micales, J.A., and K.E. Skog. 1997. The decomposition of forest products in landfills. Int. Biodeterior. Biodegrad. 39(2-3):145-158.
Moulton, R.J., and K.R. Richards. 1990. Costs of Sequestering Carbon Through Tree Planting and Forest Management in the United States. Gen. Tech. Rep. WO-58. USDA Forest Service, Washington, DC. 46 pp.

Murrell, J.D., K.H. Hellman, and R.M. Heavenrich. 1993. Light-Duty Automotive Technology and Fuel Economy Trends Through 1993. Technical Report EPA/AA/TDG/ 93-01. US Environmental Protection Agency Office of Air and Radiation, Ann Arbor, MI.

Nowak, D.J. 1994. Atmospheric carbon dioxide reduction by Chicago's urban forest, pp 83-94. In McPherson, E. G., D.J. Nowak, and R.A. Rowntree (Eds.). Chicago's Urban Forest Ecosystem: Results of the Chicago Urban Forest Climate Project. Gen. Tech. Rep. NE-186. USDA Forest Service, Northeastern Forest Experiment Station, Radnor, PA.

Nowak, D.J., and D.E. Crane. 2001. Carbon storage and sequestration by urban trees in the USA. Environ. Pollut. 116(3):381-389.

Nowak, D.J., J.R. McBride, and R.A. Beatty. 1990. Newly planted street tree growth and mortality. J. Arboric. 16(5):124-129.

Rothrock, D.A.,Y.Yu, and G.A. Maykut. 1999.Thinning of the Arctic sea-ice cover. Geophys. Res. Lett. 26 (23):34693472 .

Scheu, S., and J. Schauermann. 1994. Decomposition of roots and twigs: Effects of wood type (beech and ash), diameter, site of exposure and macro fauna exclusion. Plant Soil 163:13-24.

Schlaegel, B.E. 1981. Willow Oak Volume and Weight Tables for the Mississippi Delta. Research Paper SO-173. USDA Forest Service Southern Forest Experiment Station, New Orleans, LA. 14 pp.

Schlaegel, B.E. 1984a. Green Ash Volume and Weight Tables. Research Paper SO-206. USDA Forest Service Southern Forest Experiment Station, New Orleans, LA. 14 pp.

Schlaegel, B.E. 1984b. Overcup Oak Volume and Weight Tables. Research Paper SO-207. USDA Forest Service Southern Forest Experiment Station, New Orleans, LA. 14 pp.

Schlaegel, B.E. 1984c. Sweetgum Volume and Weight Tables. Research Paper SO-204. USDA Forest Service Southern Forest Experiment Station, New Orleans, LA. 14 pp.

Schneider, S.H. 1989. The changing climate. Sci.Am. 261(3):7079.

Sedjo, R.A. 1989. Forests to offset the greenhouse effect. J. For. $87: 12-15$.

Stanek, W., and D. State. 1978. Equations Predicting Primary Productivity (Biomass) of Trees, Shrubs and Lesser Vegetation Based on Current Literature. Publ. BC-X-183. Canadian Forestry Service,Victoria, BC. 58 pp.

Tritton, L.M., and J.W. Hornbeck. 1982. Biomass Equations for Major Tree Species of the Northeast. General Technical Report NE-69. USDA Forest Service Northeastern Forest Experiment Station, Broomall, PA. 46 pp. 
U.S. Department of Energy. 1994. Sector-Specific Issues and Reporting Methodologies Supporting the General Guidelines for the Voluntary Reporting of Greenhouse Gases Under Section 1605(b) of the Energy Policy Act of 1992.Volume 2. Publ. DOE/PO-0028. U.S. Department of Energy, Washington, DC.

U.S. Environmental Protection Agency. 1991. Non-Road Engine and Vehicle Emission Study-Report. Report No. EPA 460/3-91-02. U.S. Environmental Protection Agency, Office of Mobile Services, Ann Arbor, MI.

Wenger, K.F. (Ed.) 1984. Forestry Handbook. John Wiley and Sons, New York, NY. 1335 pp.

Acknowledgments. The authors thank ACRT for data on equipment run-time estimates, Drs. Bob Blanchette, Jessie Micales, and Ken Skog for information on decomposition rates, Drs. Bill Charmley and Lois Platte for emissions information, and Drs. Henry Gerhold and Linda Heath for reviewing an earlier draft of this manuscript.

\section{${ }^{1 *}$ Project Leader \\ ${ }^{2,3}$ Forester \\ USDA Forest Service, Northeastern Research Station c/o 5 Moon Library, SUNY-ESF \\ Syracuse, NY 13210, U.S.}

\section{${ }^{4}$ Technical Advisor \\ Davey Resource Group \\ 6050 Hicks $R d$. \\ Naples, NY 14512, U.S. \\ *Corresponding author}

Résumé. Les arbres séquestrent et emmagasinent le carbone dans leurs tissus à des quantités et des taux différents, et ce en fonction de divers facteurs tels la taille de l'arbre à maturité, l'espérance de vie et le taux de croissance. Concurremment, les pratiques d'entretien des arbres relâchent dans l'atmosphère du carbone, et ce en se basant sur les émissions de carburants fossiles provenant des équipements d'entretien (ex.: scies mécaniques, camions, déchiqueteurs, etc.). Des choix de gestion comme la localisation des arbres en fonction de la conservation d'énergie et les méthodes de disposition des arbres après leur abattage affectent également l'effet net du carbone sur les forêts urbaines. Différentes espèces, ainsi que divers scénarios de décomposition, de conservation énergétique et d'entretien, ont été évalués pour déterminer comment ces facteurs influencent l'impact net du carbone des forêts urbaines et de leur gestion. Si le carbone (via la combustion des carburants fossiles) est utilisé pour maintenir la structure de la végétation et sa santé, les écosystèmes forestiers urbains vont éventuellement devenir des émetteurs nets de carbone, à moins que les réductions secondaires de carbone (ex.: conservation énergétique) ou la limitation de la décomposition via l'emmagasinage à long terme du carbone (ex.: produits du bois, remplissage des terrains) puissent s'accomplir afin de compenser les émissions de carbone liées à l'entretien. Les pratiques de gestion pour maximiser les bénéfices nets des forêts urbaines sur la gaz carbonique atmosphérique sont discutées.

Zusammenfassung. Bäume speichern in ihrem Gewebe in Abhängigkeit von ihrer ausgewachsenen Größe, ihrer Lebensspanne und ihrer Wachstumsrate Kohlenstoff in unterschiedlichen Zeiten und Mengen. Baumpflegemaßnahmen führen Kohlenstoff zurück in die Atmospäre durch die Verbrennungsrückstände von Maschinen. Die Wahlmöglichkeiten des Managements in Bezug auf energieerhaltende Baumstandorte und Baumverwertungsmethoden nach dem Entfernen, beeinflussen ebenfalls den Netto-Kohlenstoffanteil in kommunalen Forsten. Wenn Kohlenstoff (durch Verbrennung) genutzt wird, um Vegetationsstrukturen und -gesundheit zu erhalten, können Stadtforste Kohlenstoff emittieren, falls nicht sekundäre Kohlenstoffreduktionen (z.B. Energieerhaltung) oder limitierte Kompostierung durch Langzeitspeicherung von Kohlenstoff (z.B. Holzprodukte) dadurch begleitet werden, dass sie die Erhaltung von Kohlenstoffemissionen stören. Die Managementpraxis zur Maximierung von positiven Effekten der Stadtwälder auf das atmosphärische Kohlendioxid werden hier diskutiert.

Resumen. Se estudia la captura y almacenamiento de carbono en los tejidos de los árboles a diferentes tasas y cantidades con base en factores tales como tamaño del árbol en la madurez, esperanza de vida y tasa de crecimiento. Las prácticas de cuidado de los árboles emiten carbono de nuevo a la atmósfera debido a las emisiones de los combustibles fósiles del equipo de mantenimiento (motosierras, camiones, trituradoras, etc.) Las decisiones de manejo tales como la localización de los árboles para conservación de energía y los métodos de disposición después de la remoción, también tienen efecto en el carbón neto en los bosques urbanos. Se evaluaron diferentes especies, descomposición, conservación de energía y escenarios de mantenimiento para determinar de qué manera estos factores influyen en el impacto de carbón neto de los bosques urbanos y su manejo. Si el carbono (vía combustión fósil) es usado para mantener la estructura y salud de la vegetación, los ecosistemas forestales urbanos eventualmente se convertirán en emisores netos de carbono a menos que puedan llevarse a cabo reducciones secundarias de carbono (conservación de energía) o limitando la descomposición vía almacenamiento de carbono a largo plazo (productos de madera, rellenos sanitarios) para mantener las emisiones de carbono. Son discutidas las prácticas de mantenimiento para maximizar los beneficios netos de los bosques urbanos sobre el dióxido de carbono atmosférico. 